\title{
PROPOSAL
}

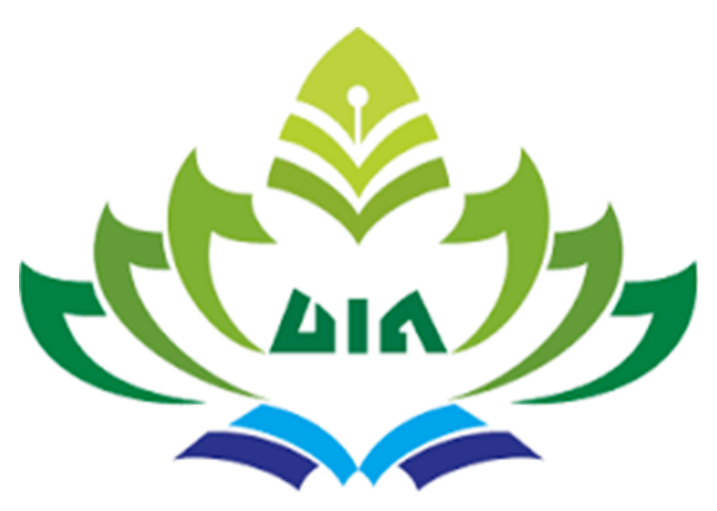

RENCANA IMPLEMENTASI SARANA PRASARANA TEKNOLOGI INFORMASI TERINTEGRASI

DAN PENGEMBANGAN SMARTCLASS

Syafrimen, M.Ed, Ph.D

Kepala Pusat Teknologi Informasi dan Pangkalan Data (PTIPD)

UNIVERSITAS ISLAM NEGERI RADEN INTAN LAMPUNG 


\section{RENCANA IMPLEMENTASI SARANA PRASARANA TEKNOLOGI INFORMASI TERINTEGRASI DAN PENGEMBANGAN SMARTCLASS}

\section{A. LATAR BELAKANG}

Informasi merupakan suatu hal yang sangat berharga dan diperhitungkan di dalam kehidupan ini. Suatu informasi yang baik akan mempunyai nilai yang tinggi jika informasi itu memang diharapkan oleh kelompok atau seseorang. Di dalam Era Globalisasi saat ini perkembangan teknologi informasi yang cepat dan juga memberikan kemudahankemudahan dalam berbagai aspek kehidupan.

Pendidikan, pengajaran dan pelatihan bergerak di empat nilai. Pertama, nilai pragmatis untuk mempertahankan kehidupan sehari-hari. Kedua, nilai personal untuk bertumbuh menjadidewasa, berinisiatif, kreatif, bertanggung jawab dan karenanya mandiri. Ketiga, nilai sosial-emosional untuk menjadi berdaya dan merdeka lewat proses saling memberdayakan dan saling memerdekakan. Keempat, nilai moralspiritual untuk mengalami pencerahan jiwa/rohani.

Paradigma pendidikan seyogyanya selalu mengacu pada kualitas yang berkelanjutan, dan bahwa kualitas yang berkelanjutan yang dilandasi kreativitas, dan produktivitas pribadi sivitas dapat dirangsang oleh pola manajemen yang berasaskan otonomi dan harus senapas dengan akuntabilitas (pertanggungjawaban), dan bahwa hak masyarakat untuk memperoleh informasi yang handal dan sahih mengenai penyelengaraan, kinerja dan hasil diaktualisasikan melalui proses akreditasi dan bahwa tindakan manajerial utama yang melandasi pengambilan keputusan dan perencanaan di lembaga pendidikan adalah proses evaluasi. Dengan demikian pengelolaan manajemen lembaga pendidikan harus berorientasi pada prisma hubungan keterkaitan antara lima komponen paradigma baru yang bermuara pada "KUALITAS" artinya, lulusan haruslah berkualitas sebagai salah satu hasil kinerja seolah yang dikelola dengan manajemen lembaga pendidikan yang otonom, akuntabel, terakreditasi dan senantiasa dievaluasi.

Menyadari bahwa perkembangan teknologi dapat dijadikan sebagai sarana untuk meningkatkan mutu pendidikan atau mutu pengajaran (mutu lulusan) maka fasilitas perguruan tinggi perlu dilengkapi dengan sarana Software dan Hardware yang memadai. Beberapa produk yang dimaksud akan dilengkapi pada kegiatan ini antara lain adalah:

- Pengembangan Interkoneksi Jaringan

- Sarana dan Prasarana Data Center

- Network and Security Center Monitoring

- Smartclass

\section{B. MAKSUD DAN TUJUAN}

Maksud dan tujuan kegiatan ini adalah:

a. Hadirnya perangkat keras/lunak penunjang operasional Teknologi Informasi di UIN Raden Intan Lampung untuk meningkatkan kualitas sarana dan prasarana berbasis teknologi yang up to date dan berstandar internasional

b. Peningkatan kualitas proses kegiatan belajar mengajar serta layanan proses kegiatan belajar mengajar secara keseluruhan.

c. Memberikan kemudahan kepada Pimpinan, Dosen, Staf, Mahasiswa dan Alumni untuk mengakses informasi akademik, administrasi, dan manajemen berbasis ICT.

d. Terciptanya atmosfir akademik yang kondusif dalam lingkup UIN Raden Intan Lampung.

e. Memberikan kemudahan kepada Pimpinan, Dosen, Staf, dan Mahasiswa, untuk mengakses layanan internet dan intranet dimanapun dan kapanpun dalam lingkup UIN Raden Intan Lampung.

f. Tersedianya perangkat keras untuk mendukung terimplementasinya Sistem Informasi manajemen yang terpadu (Integrated Smart Campus) dalam lingkup UIN Raden Intan Lampung. 


\section{RENCANA PEMBANGUNAN DAN PENGEMBANGAN}

Pada kegiatan Peningkatan Sarana dan Prasarana Teknologi Informasi ini memerlukan tersedianya sarana prasarana yang memadai yakni:

\section{Interkoneksi Jaringan}

Manajemen universitas semakin membutuhkan komunikasi yang cepat dan tepat, namun tidak harus menjadi repot dan mahal. Semua jenis komunikasi dapat dibawa dalam satu media pembawa, tidak peduli apakah itu suara, video, teks, grafik, data, dan lainnya (kebutuhan seperti ini sering disebut dengan istilah Triple Play). Media yang mampu melayani kebutuhan seperti inilah yang disebut Next Generation Network atau sering disingkat NGN. Untuk menjawab kebutuhan Triple Play tersebut, para perangcang teknologi komunikasi telah menciptakan berbagai teknologi yang mampu memenuhi kebutuhan tersebut. Aplikasi NGN sangat membutuhkan sebuah jaringan yang dapat dilewati data dalam jumlah yang sangat besar, dapat melakukan transfer data dengan sangat cepat, lebih kebal terhadap masalah-masalah komunikasi, dan yang terpenting haruslah murah dan mudah dalam implementasinya.

Teknologi serat optik (fiber optic) akan memberikan kemungkinan yang lebih baik bagi jaringan telekomunikasi, terutama dalam hal komunikasi data. Serat optik adalah salah satu media transmisi yang dapat menyalurkan informasi dengan kapasitas besar dengan tingkat keandalan (performance) yang tinggi. Berbeda dengan media transmisi lainnya, maka pada teknologi serat optik ini gelombang pembawanya tidak lagi merupakan gelombang elektromagnet (microwave) atau listrik, akan tetapi merupakan sinar atau cahaya laser.

Kondisi saat ini masih terdapat beberapa titik jaringan interkoneksi lokal di UIN Raden Intan Lampung belum terhubung dengan jaringan utama. Diharapkan melalui kegiatan ini akan memaksimalkan seluruh area gedung di UIN Raden Intan Lampung terkoneksi dengan Jaringan Fiber Optic maupun Wireless Network.

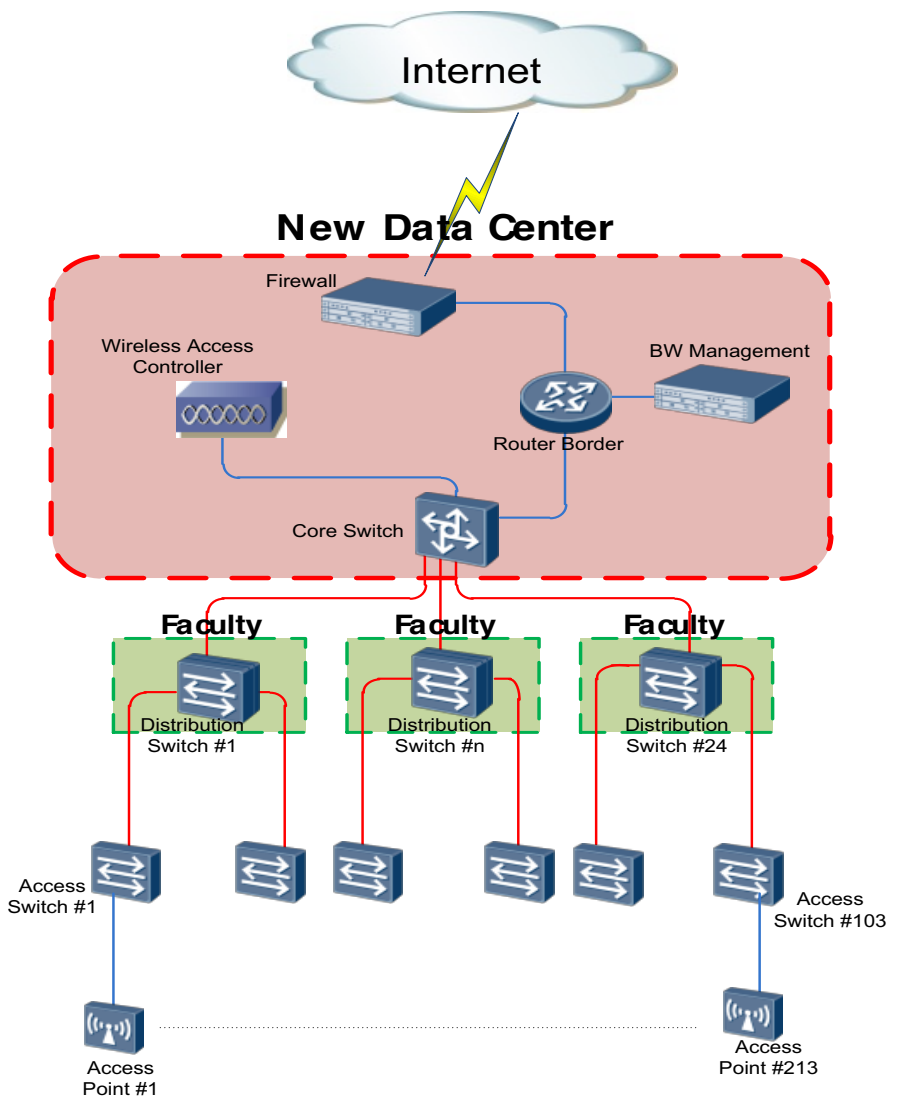

Design Topology komponen network 


\section{TOPOLOGI FIBER OPTIC}

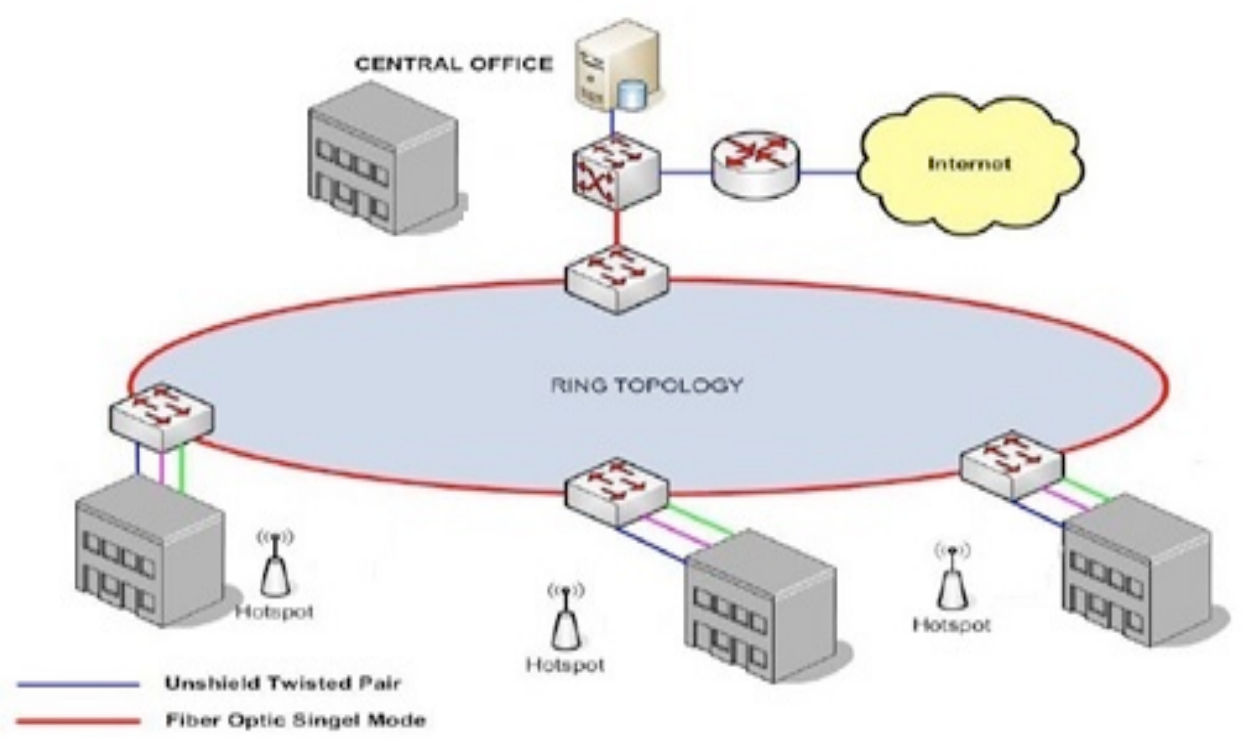

Rencana desain untuk interkoneksi jaringan Fiber Optic di UIN Raden Intan Lampung 
Teknis pemasangan akan dilakukan sebagai berikut:
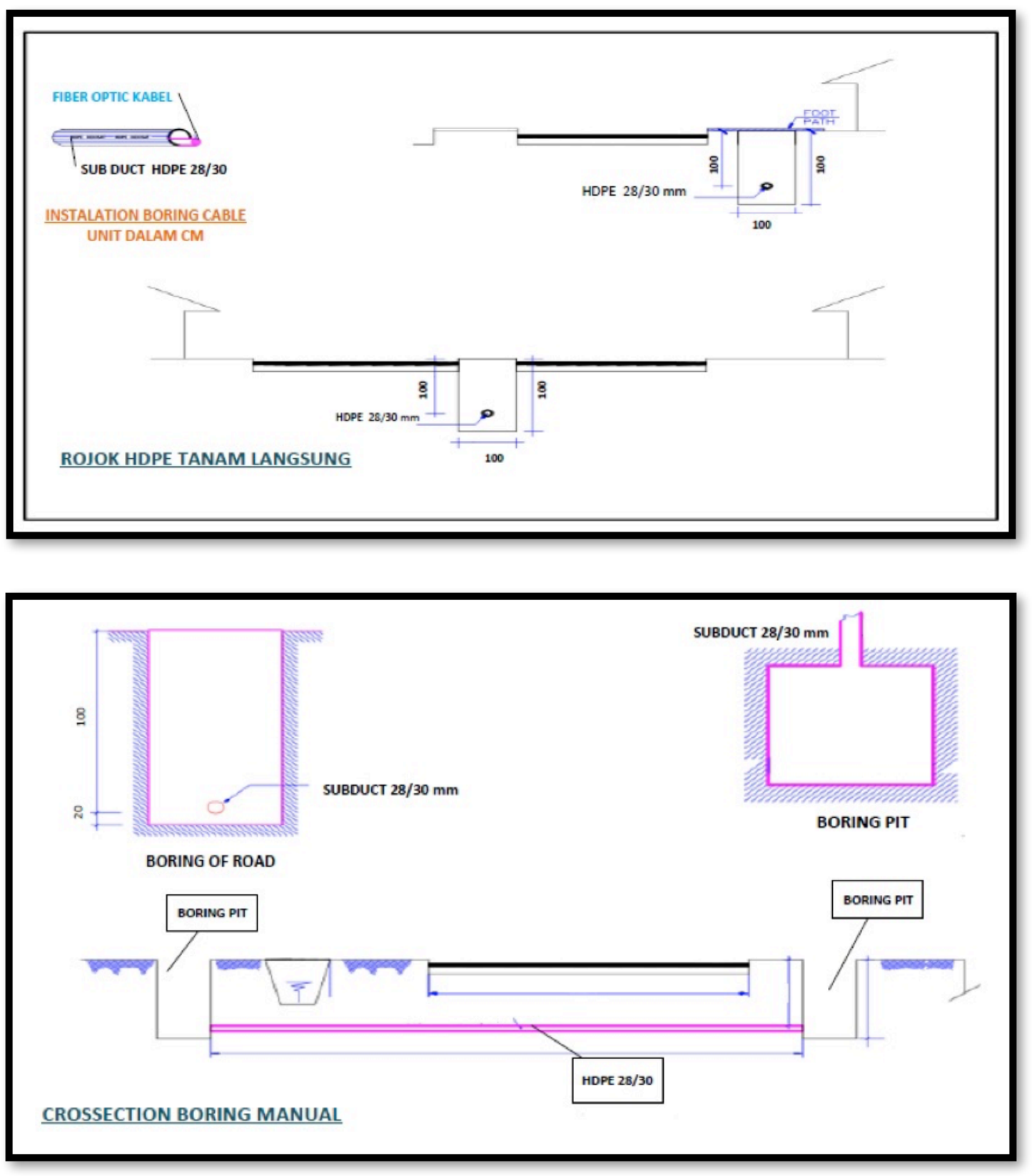

\section{Data Center}

Data Center yang secara harafiah berarti pusat data, adalah suatu fasilitas untuk menempatkan sistem komputer dan equipment-equipment terkait, seperti sistem komunikasi data dan penyimpanan data. Fasilitas ini mencakup daya redundant, koneksi komunikasi data redundant, pengontrol lingkungan, pencegah bahaya kebakaran, serta piranti keamanan fisik. Pada era ICT, Information and Communication Technology, saat ini, Data Center telah menjadi satu issue penting di dunia, khusunya bagi para pelaku bisnis. Sebagai inti dari layanan bisnis, maka Data Center harus mampu memberikan layanan optimal, sekalipun terjadinya suatu bencana, sehingga bisnis dalam suatu korporasi akan tetap bertahan hingga menghasilkan laba. Berawal dari peran Data Center yang sangat signifikan, serta dikaitkan dengan berbagai issue yang ada pada Data Center saat ini, terutama Disaster Recovery Planning, maka kajian secara komprehensif dan holistik mengenai Data Center, telah menjadi critical issue bagi suatu institusi bisnis sebagai user dan profitable issue bagi produsen penyedia infrastruktur dan equipment Data Center. Secara umum Data Center terbagi dua berdasarkan fungsinya :

- Internet Data Center, biasanya hanya dioperasikan untuk kebutuhan Internet Service Provider

- Corporate Data Center, dimiliki oleh suatu korporasi atau institusi, untuk mengoperasikan proses bisnis, dengan menggabungkan layanan Internet dan Intranet. 
Aspek-aspek yang harus diperhatikan saat mendesain dan merencanakan Data Center adalah:

Lokasi yang aman serta memenuhi syarat sipil bangunan, geologi, vulkanologi dan topografi. Mempunyai sistem cadangan, untuk sistem catudaya, pengatur udara/lingkungan dan komunikasi data. Serta menerapkan tata kelola standar Data Center, meliputi : Standar Prosedur Operasi, Standar Prosedur Perawatan, Standar dan Rencana Pemulihan dan Mitigasi Bencana, serta Standar Jaminan Kelangsungan Bisnis.

Kriteria perancangan sebuah Data Center yang ideal:

- Availability atau Ketersediaan Data Center diciptakan untuk mampu memberikan operasi yang berkelanjutan dan terus-menerus bagi suatu Universitas baik dalam keadaan normal maupun dalam keadaan terjadinya suatu kerusakan yang berarti atau tidak. Data Center harus dibuat sebisa mungkin mendekati Zero-Failure untuk seluruh komponennya.

- Scalability dan Flexibility Data Center harus mampu beradaptasi dengan pertumbuhan kebutuhan yang cepat atau ketika adanya servis baru yang harus disediakan oleh Data Center tanpa melakukan perubahan yang cukup berarti bagi Data Center secara keseluruhan.

- Security Data Center menyimpan berbagai aset Universitas yang berharga, oleh karenanya sistem keamanan dibuat seketat mungkin baik pengamanan secara fisik maupun pengamanan non-fisik.

Tier atau Level pada Data Center merupakan perancangan Data Center yang berangkat dari kebutuhan yang ada, dan kemudian didefinisikan pada berbagai perlengkapan IT yang diperlukan beserta pemilihan teknologi berbarengan dengan perencanaan infrastruktur Data Center yang lain. Menurut Telecommunication Industry Association (ANSI/TIA-942), ada 4 Tier atau 4 Level dalam perancangan Data Center, yang setiap tiernya menawarkan tingkat availabilitas yang berbeda disesuaikan dengan kebutuhan suatu Data Center, diantaranya :

1. Tier-I (Basic),

2. Tier-II (Redundant Components),

3. Tier-III (Concurently Maintainable)

4. Tier-IV (Fault Tolerance).

Maraknya isu lingkungan hidup terutama Global Warming telah menjadi tema sentral saat ini, tidak terkecuali bagi pelaku bisnis teknologi ICT. Ada berbagai sorotan, gagasan, dan usulan ICT yang berbasis kepada upaya penyelamatan lingkungan hidup demi kemaslahatan umat pada masa yang akan datang, diantaranya Data Center. Selama ini, keberadaan Data Center identik dengan: kebutuhan catu daya listrik yang sangat besar untuk proses komputasi yang kontinnyu (Non Stop), yang akan berdampak pada permasalahan energi. Dari permasalahan tersebut, dibutuhkan model baru Data Center yang ramah lingkungan atau Green Data Center.

Untuk menerapkan Green Data Center, dilakukan efisiensi Data Center, menggunakan Modular Data Center, sebuah konsep Data Center baru untuk lingkungan yang memiliki kebutuhan komputasi tingkat tinggi. Sistem Modular Data Center tersebut merupakan sebuah solusi yang lengkap dan efisien karena:

a. Tidak membutuhkan raised floor, sehingga sesuai untuk dipasang hanya di ruangan kerja.

b. Menyediakan sistem power, cooling, monitoring, dan penyimpanan perangkat aktif dalam satu box.

c. Desain serta instalasi yang mudah dan sederhana.

Dengan solusi ini maka akan tercipta sebuah Data Center yang hemat biaya perawatan, menghemat tempat/ruangan, ramah lingkungan (hemat energy), dan fleksibel karena lebih mudah untuk pengembangan/ penambahan dengan system modular. 


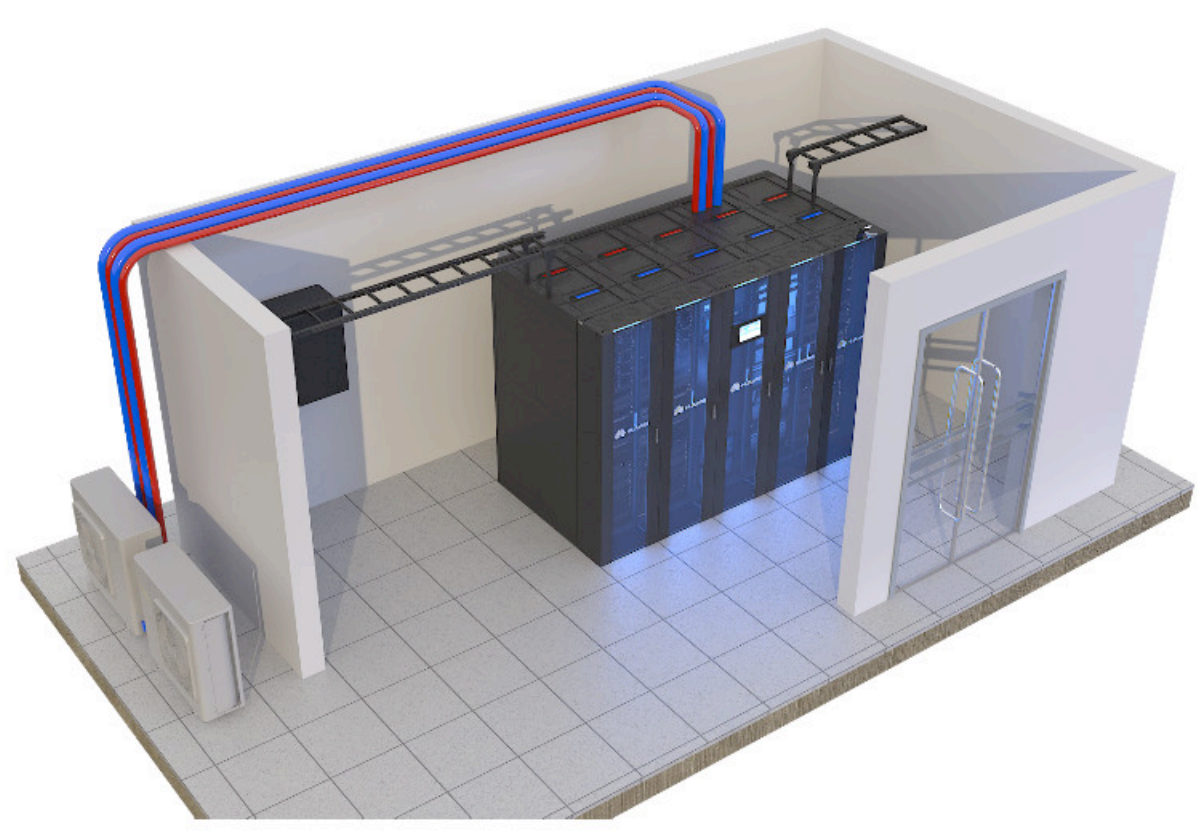

Adapun untuk sarana dan prasarana pendukung Data Center adalah sebagai berikut:

A. Network dan Security Device

1) Core Switch

Network switch yang menggabungkan beberapa device network switch menjadi satu kesatuan (integrated network) dikarenakan end user yang terkoneksi ke dalam suatu jaringan memiliki jumlah yang banyak, sehingga kita perlu melakukan trunking (menyambungkan switch satu dengan switch lain) antar network switch secara bertingkat. Bisa menggunakan koneksi 1G/10G untuk mendistribusikan data ke perangkat lainnya. Core switch ini bertanggung jawab untu mengirim traffic scara cepat dan andal.

2) Distribution Server Farm Switch / Acces Switch

Server Farm Switch yang berfungsi untuk menghubungkan beberapa server dan storage ke jaringan yang ada. Dengan menggunakan koneksi Gigabit Ethernet maka trafik jaringan ke Server dan storage akan lebih cepat. Pada layer ini sering disebut juga workgroup layer, merupakan titik komunikasi antara access layer dan core layer. Fungsi utamanya adalah routing, filtering, akses WAN, dan menentukan akses core layer jika diperlukan. Menentukan path tercepat/terbaik dan mengirim request ke core layer.Core layer kemudian dengan cepat mengirim request tersebut ke service yang sesuai.

3) Access Point

Access Point adalah sebuah perangkat jaringan yang berisi sebuah transceiver dan antena untuk transmisi dan menerima sinyal ke dan dari clients remote. Dengan access points (AP) clients wireless bisa dengan cepat dan mudah untuk terhubung kepada jaringan LAN kabel secara wireless. Access Point Controller adalah alat yg berfungsi untuk men-control banyak AP.

4) Firewall

Firewall menambahkan identitas user (Layer 8 identity base) pada aturan-aturan kriteria firewall terhadap asal IP, zona tujuan dan alamat IP yang telah ditetapkan berdasarkan kelompok pengguna. Juga dapat mengatur aplikasi P2P, Instant Messaging (IM) seperti YM dan mencegah pertukaran data lewat aplikasi tersebut.

5) Cabling

Cabling digunakan untuk menjaga konektivitas data baik antar gedung atau di suatu tempat atau ruangan tertentu menggunakan kabel yang memiliki performa tinggi. 
B. Network and Security Center monitoring diantaranya adalah:

1) Network Management System

Konten yang terdapat pada Network Management System adalah sebagai berikut:

1. Configuration Management

2. Fault Management

3. Performance Management

4. Security Management

- Configuration Management adalah pengaturan jaringan berupa penambahan Object, Pengurangan Object, Penambahan/Pengurangan Link, Perubahan Topology dan design yang dilakukan terhadap jaringan yang ada ataupun jaringan yang akan dibuat.

- Fault Management adalah pengaturan jaringan berupa proses deteksi kesalahan di Object maupun di jaringan tersebut yang diinformasikan dalam wujud alarm ataupun peringatan yang disampaikan oleh system dan telah diatur prosesnya.

- Performance Management adalah pengaturan jaringan berupa monitoring kinerja dari Object maupun jaringan dalam rentang waktu tertentu maupun pada saat jaringan berjalan (Current).

- Security Management adalah pengaturan jaringan berupa System keamanan dalam mengakses jaringan sehingga jaringan tidak sembarangan dapat diubah maupun di salah gunakan atau diakses oleh pihak-pihak yang tidak berkompeten dan bertanggungjawab.

2) Security Information and Event Management System

Security Information and Event Management (SIEM) adalah system informasi keamanan terpusat yang mengoleksi informasi dan kejadian/event security dari jaringan. Semua informasi dan event diolah dan ditampilkan dalam bentuk laporan, graph, dll. Dengan kata lain, SIEM adalah system informasi yang mencakup fungsi integrasi data, korelasi data, deteksi dan alert, reporting, serta penyimpanan data.

3) Gateway Antivirus dan AntiSpyWare

AntiVirus akan memeriksa semua email dan web yang lewat internet dan mengkarantina dan blok ancaman yang akan masuk ke dalam jaringan komputer. memberikan proteksi real-time melawan semua program penyusup (spyware/malware), termasuk virus, Worm, Backdoor, Trojan, Keyloggers. Cybroam akan mengupdate otomatis antivirus setiap setengah jam agar memberikan perlindungan terkini.

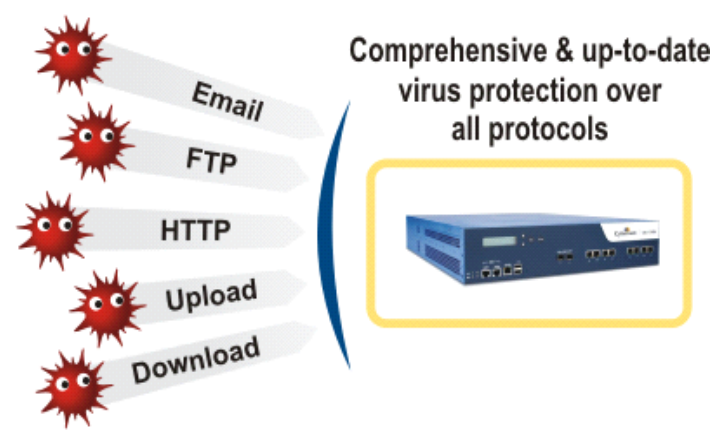

4) Gateway Anti-Spam

Spam dan malware datang bersamaan email dan menjadi salah satu faktor utama terkena virus. Pembuat spam yang canggih akan menggunakan program robot jaringan (bonets) untuk menghancurkan pertahanan spam konvensional sehingga dapat mencuri data rahasia keuangan. Beberapa serangan tak dapat dideteksi dengan solusi anti spam tradisional. Enterprise membutuhkan pertahanan yang realible sehingga dapat menganalisa konten, asal dan pola distribusi email, sehingga dapat efektif menproteksi serangan melawan spam dan malware.

5) Kebijakan Berdasarkan Identitas User

Setiap pengguna komputer dalam jaringan dapat dikelompokan berdasarkan fungsi pekerjaan agar memudahkan pengelolaan jaringan. Kelompok staf pemasaran, keuangan, gudang, personalia dan 
lainnya. Masing masing kelompok atau user dapat dibuat kebijakan akses jaringan seperti gambar berikut.

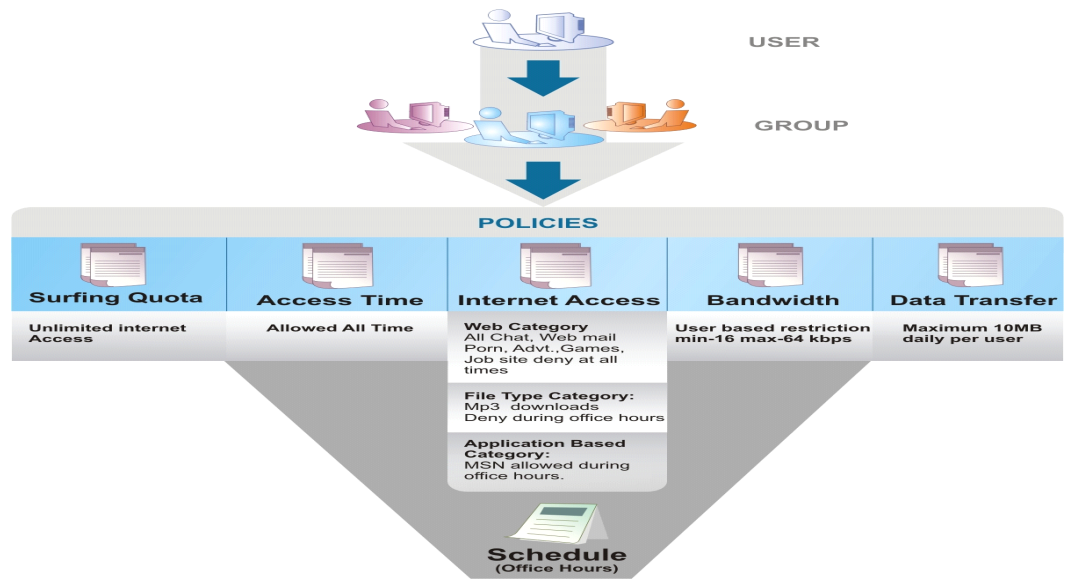

6) Bandwidth Management

Penggunaan internet, terutama untuk mengunduh file video, lagu MP3, foto resolusi tinggi oleh user internal, akan memboroskan pemakaian badwidth internet dan dapat memperlambat aplikasi yang membutuhkan kestabilan koneksi internet. Manajemen penggunaan bandwidth internet tiap user dapat diatur dengan mudah, bahkan waktu mengunduhan filepun dapat diatur dan dibatasi kapasitasnya.

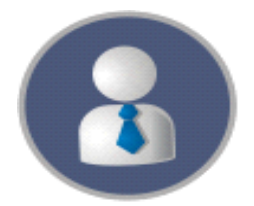

CEO $1 \mathrm{mbps}$

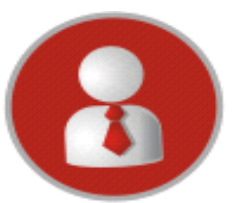

Manager 256 kbps

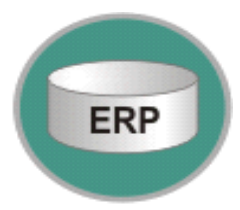

ERP System 4 mbps

Masing-masing jajaran pejabat dapat dikelompokan besar bandwidth internet berdasarkan tugas dan fungsinya.

7) Web Content Filtering atau lebih dikenal dengan "Internet Sehat"

Dapat mengatur dan mencegah user masuk ke web/situs yang tak diinginkan, misalnya situs pornografi, berita, hiburan download video yang akan menghabiskan bandwidth internet. Dapat mengklasifikasi jutaan web internet menjadi lebih dari 82 group, sehingga hai ini akan sangat mempermudah administrator jaringan komputer untuk memblokir situs yang merugikan institusi atau Universitas

Selain perangkat-perangkat utama diatas, banyak sarana dan prasarana IT lainnya yang perlu ditambahkan guna menunjang koneksitas, stabilitas, dan keamanan dalam mencapai Integrated Smart Campus, diantaranya adalah:

1) Fire Extinguisher Aerosol

Fire extinguisher dengan teknologi aerosol akan menanggulangi jika terjadi kebakaran. Teknologi aerosol ini merupakan teknologi baru yang canggih di mana saat adanya trigger yang didapat dari sensor terkait asap dan api, fire extinguisher akan membuka dan menyebarkan gas pemadam ke sekitarnya dalam waktu yang sangat singkat. Keunggulan dari fire extinguisher berjenis aerosol ini adalah gas yang dihasilkan tidak merusak peralatan elektronik yang ada serta memenuhi standarisasi internasional untuk memadamkan api. Selain itu, gas ini tidak menimbulkan bekas yang banyak terhadap setiap perangkat yang terkena semburan dari gas yang dihasilkan. 


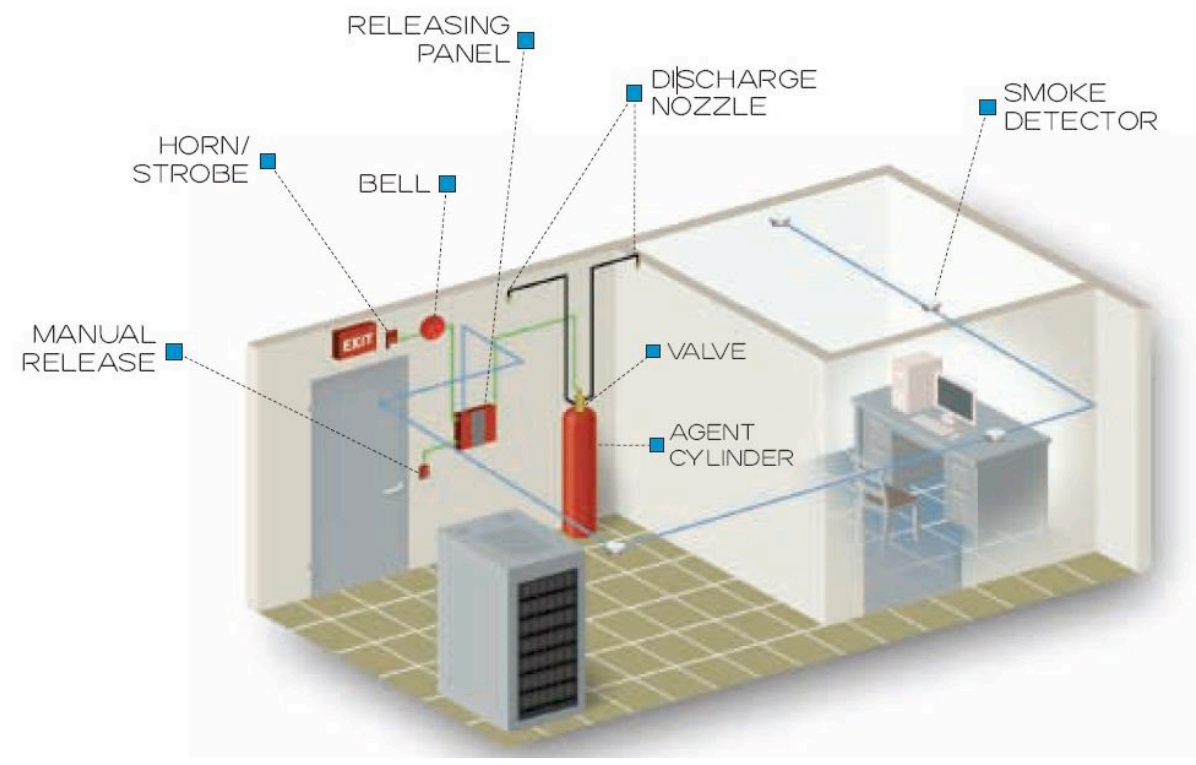

2) Camera Security System

Seluruh data yang berada di dalam ruangan data center tentu sangat penting dan pada umumnya terdapat beberapa data yang bersifat sangat confidential. Oleh sebab itu, dengan adanya camera security system yang terpasang di dalam ruangan data center dapat meningkatkan keamanan data center yang akan membantu kita untuk memantau ruangan data center selama $24 \times 7$ secara penuh. Pantauan tersebut pun tersimpan ke dalam media penyimpanan sehingga dapat dilihat kembali dan melakukan penelitian kondisi ruangan data center pada suatu saat tertentu di saat tidak dipantau secara langsung oleh kita.

\section{3) Access Door}

Tidak sembarang personal yang boleh memasuki ruangan data center. Dengan adanya access door, maka kita dapat mengkontrol untuk membatasi siapa saja yang diijinkan masuk ke dalam ruang server. Dengan begitu hanya orang yang berkepentingan saja yang dapat memasuki ruangan data center dan keamanan ruangan data center menjadi lebih ketat.

\section{4) Genset}

Genset atau yang merupakan singkatan dari generator set sudah kita ketahui bersama sangat bermanfaat untuk bisa menyuplai tenaga listrik yang dibutuhkan bagi ruangan data center secara keseluruhan dan dalam waktu yang lama (bergantung kepada jumlah bahan bakar yang dimiliki). Oleh sebab itu, kehadiran genset ini tentu sangatlah penting untuk menjaga kelangsungan proses data center apabila listrik secara tiba-tiba mati mendadak dalam jangka waktu yang lama sedangkan data center diperlukan untuk bisa tetap berjalan dengan biasa. 


\section{Smartclass}

Secara arsitektur, fasilitas Smart class yang akan dikembangkan sebagai berikut:

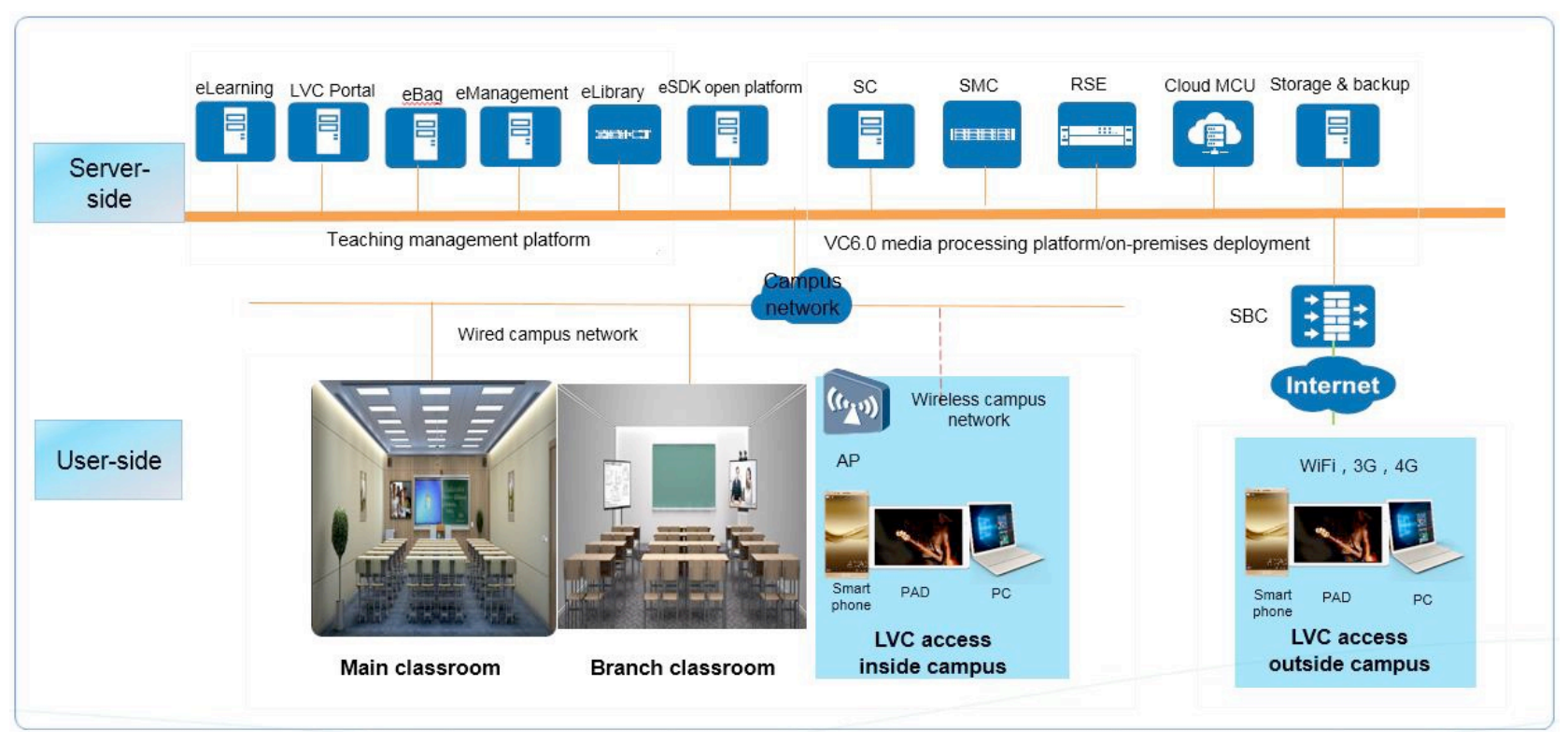

Adapun perangkat yg diperlukan adalah sbb:

1) Auto Tracking System

2) Camera, MDB, Monitor

3) Server, Storage \& Database system

4) Audio \& Video system

5) Ruangan dengan desain akustik

6) Platform Smartclass

4. Pengembangan Aplikasi Sistem Manajemen Universitas

A. Perangkat Sistem Informasi

1) Server Virtualisasi

Server Adalah sebuah sistem komputer yang digunakan untuk menjalankan Virtual server dalam sebuah jaringan komputer. Server Virtualisasi juga menjalankan perangkat lunak administratif yang mengontrol akses terhadap jaringan dan sumber daya yang terdapat di dalamnya, seperti halnya berkas atau pencetak, dan memberikan akses kepada stasiun kerja anggota jaringan.

2) Storage Utama

Merupakan perangkat penyimpanan bersifat enterprise yang menyimpan informasi, memproses informasi atau kedua-duanya. Merupakan platform yang kuat untuk menkonsolidasi penyimpanan di tingkat blok data, data dan aplikasi penyimpanan yang langsung dihubungkan ke server. Storage utama memungkinkan setiap perusahaan mengakses data menggunakan multi ptotokol koneksi (iSCSI, FC, FCoE) dengan menggunakan managemen storage yang mudah. Storage utama memiliki fitur pintar yang dapat menempatkan data pada tempat yang tepat yang kita sebut sebagai storage tiering secara otomatis

3) SAN Switch

Merupakan switch jaringan yang kompatible dengan protokol Fibre Channel. San switch merupakan komponen inti dari jaringan penyimpanan luas (SAN). SAN Switch adalah perangkat jaringan Fibre Channel yang memungkinkan komunikasi dari banyak-ke-banyak, pencarian nama perangkat, keamanan, dan redundansi. Switch FC menerapkan zonasi, mekanisme yang menonaktifkan traffic yang tidak diinginkan antara node tertentu. 


\section{B. Sistem Informasi}

Seiring dengan globalisasi dan perkembangan teknologi yang sangat pesat, maka pengelolaan manajemen perguruan tinggi dewasa ini mau tidak mau harus memanfaatkan teknologi informasi. Mulai dari penanganan masalah administrasi pada saat penerimaan mahasiswa baru, pengelolaan data akademik mahasiswa, pelaksanaan kegiatan perkuliahan, manajemen sumber daya serta proses pengambilan kebijakan dari eksekutif, dapat dilakukan secara lebih efektif dan optimal dengan menggunakan sistem informasi.

Sudah banyak sistem yang dikembangkan untuk membantu pengelolaan perguruan tinggi. Permasalahannya, kebanyakan sistem tersebut dikembangkan tidak memperhatikan kompleksitas aspekaspek manajemen internal, budaya dan kultur dari managemen perguruan tinggi, tren teknologi, serta potensi perubahan kebutuhan data yang diinginkan oleh stakeholder perguruan tinggi. Akibatnya tidak tercapai implementasi yang efisien dan berkelanjutan. Masalah lain dalam implementasi sistem informasi di perguruan tinggi adalah sering tidak disadari perlunya perubahan budaya dalam proses bisnis manajemen perguruan tinggi yang berimbas pada perubahan SOP (Standard Operating Procedures) dan perubahan fungsi unit-unit internal organisasi.

Bagi UIN Raden Intan Lampung penerapan sistem dan teknologi informasi yang handal, dan dapat memenuhi kebutuhan stakeholder dalam membantu pengelolaan perguruan tinggi merupakan keniscayaan. Pengembangan sistem dan teknologi informasi ini sejalan dengan Rencana Strategis UIN Raden Intan Lampung yang selaras dengan Renstra Diknas 2010-2014.

Oleh sebab itu, perlu adanya peningkatan sarana dan prasarana TIK dalam pelaksanaan operasional akademik termasuk menunjang manajemen (stakeholder) dalam pengambilan keputusan. Ini dapat dilakukan dengan peningkatan dan perluasan kapasitas dan kapabilitas sistem manajemen berbasis TIK dan diarahkan pada kegiatan dengan tetap memanfaatkan infrastruktur yang telah tersedia dan mengembangkan dengan infrastruktur yang baru namun sesuai dan menunjang kegiatan akademis.

Ketersediaan sistem informasi terpadu yang mampu melayani seluruh kebutuhan pokok UIN RIL memerlukan tahapan, waktu pengembangan yang panjang, serta kebutuhan sumber daya TI yang cukup dengan kompetensi memadai. Pada sisi lain, kebutuhan sistem informasi yang dapat segera digunakan cukup mendesak, baik untuk pelayanan internal maupun eksternal. Untuk mengatasi permasalahan ini, maka dapat diperlukan skenario yang tepat.

Usulan skenario pengembangan sistem informasi adalah sebagai berikut:

1) Tahap I: menggunakan aplikasi siap pakai berbasis cloud (SaaS -software as a services) dengan kriteria:

a. Adanya dukungan mitra untuk mempersiapkan data (pengumpulan data, data cleansing, dan migrasi data) sehingga UIN Raden intan memperoleh benefit tersedianya data yang akurat dan komprehensif tanpa duplikasi yang tidak perlu;

b. Adanya dukungan mitra untuk penyelarasan proses bisnis yang streamline dan mereduksi duplikasi proses yang tidak perlu;

c. Adanya dukungan mitra untuk menyediakan aplikasi yang mencakup seluruh proses bisnis baik akademik maupun manajemen secara komprehensif dan terpadu;

d. Adanya dukungan mitra untuk menyediakan aplikasi yang mampu mendukung penyediaan feeding data ke PDDIKTI, EMIS, dan proses akreditasi secara cepat, tepat, dan terotomasi;

e. Adanya jaminan keamanan data yang dimiliki UIN Raden Intan, yang dijelaskan secara rinci baik secara teknis maupun manajemen;

f. Ketersediaan aplikasi mobile siap pakai yang terintegrasi dengan aplikasi yang disediakan, baik berbasis android maupun iOS;

g. Ketersediaan technical support selama 24 jam x 7 hari, dalam penanganan permasalahan teknis; 
h. Ketersediaan pendampingan teknis sesuai kebutuhan.

2) Tahap II: mempersiapkan SDM TI secara terencana dan bertahap untuk merintis pembangunan dan pengembangan aplikasi sistem informasi. Pembangunan dan pengembangan aplikasi dapat merujuk aplikasi cloud yang disewa, dengan memanfaatkan infrastruktur TI saat ini sebagai sarana pengembangan (development lab).

3) Tahap III: melakukan pengembangan aplikasi sendiri secara bertahap menuju kemandirian UIN Raden Intan.

Skenario ini diusulkan dengan harapan agar proses transformasi penerapan sistem informasi UIN Raden Intan dapat dilakukan secara smooth dan cepat. Quick win penerapan sistem informasi dapat dilakukan secara menyeluruh dalam waktu yang relatif cepat, dan mengurangi proses trial \& error.

\section{STRATEGI PENCAPAIAN KELUARAN}

a. Metode Pelaksanaan.

Program ini akan dilaksanakan oleh UIN Raden Intan Lampung dengan melibatkan pihak lain yang berkompeten.

b. Tahapan Pelaksanaan.

Tahapan pelaksanaan kegiatan ini adalah dengan melakukan pengadaan perangkat keras dan pengembangan perangkat lunak yang dibutuhkan serta sarana dan prasarana pendukungnya.

\section{E. WAKTU PENCAPAIAN KELUARAN}

Kegiatan ini akan dilaksanakan pada Tahun 2018-2019, dengan pencapaian keluaran kegiatan ini paling lambat akhir bulan Desember Tahun 2019. 